\title{
PENGEMBANGAN BUKU SAKU BAHASA JEPANG PARIWISATA UNTUK CADDY DI NIRWANA BALI GOLF CLUB
}

\author{
N.W. Nilawati ${ }^{1}$, K.E.K. Adnyani ${ }^{2}$, N.N. Suartini ${ }^{3}$ \\ Jurusan Bahasa Asing, Universitas Pendidikan Ganesha, Singaraja \\ email : ni.wayan.nilawati@undiksha.ac.id, khrisna.adnyani@undiksha.ac.id, nn.suartini@undiksha.ac.id,
}

\begin{abstract}
Abstrak
Tujuan dari penelitian ini adalah untuk mengembangkan buku saku bahasa Jepang pariwisata yang sesuai dengan kebutuhan caddy di Nirwana Bali Golf Club. Model pengembangan yang digunakan dalam penelitian ini adalah ADDIE (Analysis-Design-Development-Implementation-Evaluation). Dalam penelitian ini, digunakan metode (1) observasi lapangan, (2) wawancara, (3) kuesioner berupa angket uji ahli (aji ahli materi, uji ahli media dan uji ahli kelayakan) untuk membantu proses pengembangan dan perbaikan produk. Berdasarkan angket uji ahli, total skor untuk ahli materi adalah $85 \%$ dengan kualifikasi 'baik', total skor untuk ahli media adalah $80 \%$ dengan kualifikasi 'baik' dan total skor untuk ahli uji kelayakan adalah $92 \%$ dengan kualifikasi 'sangat baik'. Dengan demikian berdasarkan hasil analisis data tersebut dapat disimpulkan bahwa pengembangan buku saku bahasa Jepang pariwisata untuk caddy di Nirwana Bali Golf Club sudah sesuai standar serta siap digunakan untuk membantu caddy dalam memahami serta mengaplikasikan penggunaan kosakata bahasa Jepang pariwisata secara komunikatif.
\end{abstract}

Kata Kunci : Pengembangan Media, Buku Saku, kosakata bahasa Jepang Pariwisata.

\begin{abstract}
要旨
本研究の目的は、ニルワナバリゴルフクラブのキャディーのニーズに合った日本の観光ポケットブッ ク を開発することである。研究で使用した開発モデルは ADDIE (分析、設計、開発、実装、評価) で ある。本研究で使用するモデルは (1) 現地観察、(2) インタビュー、(3) 専門家への試験質問票 (内容、メ ディア、資格の専門家) 製品の開発および改善プロセスをサポートするために使用されである。専門 家への質問に基づくと、内容の専門家の合計スコアのパーセンテージは 85 パーセンテージ「良い」、 メディア専門家の合計スコアのパーセンテージは 80 パーセンテージ「良い資格である、書籍適格 性テストは 92 パーセンテージ「とても良い」資格であった。それに、データ分析の結果から、ニ ルヴァーナバリゴルフクラブでの日本のキャディートラベルポケットブックの開発は基準を満たし てい ると結論付けることができである。キャディがコミュニカティブな日本の語彙を理解して適用す るのを 助けるために使用する準備ができる。
\end{abstract}

キーワード: メディア開発、ポケットブック、日本の観光語彙。

\section{Pendahuluan}

Salah satu bidang pekerjaan yang membutuhkan kemampuan bahasa asing yang baik adalah pekerjaan di dalam bidang pariwisata. Bidang pariwisata menjadi salah satu andalan bagi pemerintah Indonesia dalam memperoleh devisa. Hal ini dikarenakan adanya keanekaragaman alam serta budaya yang terdapat di Indonesia yang dapat menarik minat wisatawan untuk datang berkunjung ke Indonesia. Selain kedua hal tersebut faktor penting yang menjadikan Indonesia tujuan wisatawan adalah keramahtamahan yang menjadi ciri khas di dalam diri warganya yang membuat wisatawan merasa nyaman dan aman berada di Indonesia.

Berdasarkan data TripAdvisor pada tahun 2019 pulau Bali merupakan tempat tujuan nomor satu wisatawan dunia.Wisatawan dari belahan dunia manapun datang berkunjung 
untuk menikmati keindahan Bali. Akan sangat menyusahkan jika para penyedia jasa pariwisata tidak mampu memberikan pelayanan terbaik karena adanya keterbatasan dalam berkomunikasi dengan menggunakan bahasa asing khususnya bahasa Jepang. Berdasarkan data dari Badan Pusat Statistik tahun 2019 Wisatawan menempati posisi ke-tiga dengan total kunjungan sebesar 519.623 ribu orang.

Bahasa Jepang merupakan salah satu bahasa internasional berdasarkan hasil penelitian terbaru tahun 2018 oleh Japan Foundation Indonesia berada di posisi nomor satu di antara negara asia tenggara pembelajar bahasa Jepang terbanyak di dunia yang mencapai angka 466.360 orang pembelajar.

Hal ini sesuai dengan hasil observasi awal di tempat Nirwana Bali Golf Club yang terletak di Hotel Pan Pasific Tanah Lot. Nirwana Bali Golf Club merupakan salah satu tempat golf terkenal di Indonesia. Pekerja di tempat tersebut memiliki standar tinggi seperti kemampuan fisik serta kemampuan berkomunikasi berbahasa asing dalam merekrut pekerja caddy guna meningkatkan mutu dan kualitas tempat tujuan pariwisata tersebut. Selama tiga bulan calon caddy dilatih dan diajarkan dasar-dasar bermain golf sebelum terjun ke lapangan, maka dari itu para caddy di Nirwana Bali Golf Club setidaknya memiliki kemampuan setara golfer amatir. Selain itu para caddy juga dituntut untuk bisa berbahasa asing agar memudahkan berinteraksi serta mengajari tamu yang datang untuk bermain golf. Namun sesuai dengan observasi awal, para caddy di sana kesulitan berkomunikasi menggunakan bahasa Jepang.

Faktor yang menyebabkan kesulitan dalam berkomunikasi dengan bahasa Jepang ialah karena ketiadaan buku pedoman yang membuat para caddy kebingungan dalam menghadapi golfer asal Jepang yang tidak menggunakan bahasa Inggris sebagai sarana berkomunikasi. Apalagi ditemukan fakta di lapangan bahwa para caddy tidak pernah diajarkan bahasa Jepang secara formal, melainkan otodidak. Sesuai dengan standar kerja yang berlaku di Nirwana Bali Golf Club bahwa semua caddy harus memiliki kemampuan bermain golf dan mengetahui teknik-teknik dasar golf serta istilah di dalam dunia golf akan lebih mudah jika adanya guide yang menemani golfer dan caddy tersebut, tetapi berdasarkan hasil wawancara yang dilakukan dengan seorang caddy yang bekerja di Nirwana Bali Golf Club, golfer asal Jepang biasanya tidak menggunakan jasa guide atau kalau pun ada, guide hanya berada di lobi hotel dan tidak ikut menemani golfer tersebut terjun ke lapangan.

Mempelajari bahasa Jepang untuk pariwisata tidak hanya membuat pekerjaan semakin mudah tetapi juga akan lebih menyenangkan karena adanya sebuah proses interaksi antara golfer dan caddy tersebut. Akan tetapi kurangnya sumber bacaan khususnya mengenai buku pariwisata untuk caddy menyebabkan ketiadaan interaksi antara golfer dan caddy karena tanpa adanya buku penunjang, caddy tidak bisa hanya belajar dari mendengar apa yang disampaikan oleh caddy senior di lapangan. Dengan adanya buku tersebut, setidaknya menumbuhkan minat mempelajari bahasa Jepang dengan lebih baik apalagi caddy merupakan pekerjaan yang harus berinteraksi langsung dengan wisatawan dari negara manapun. Hal ini sangat disayangkan karena kurangnya sumber bacaan khususnya mengenai buku pariwisata untuk caddy. Hal ini pula yang memengaruhi motivasi dan minat belajar caddy. Karena tanpa adanya buku penunjang, caddy tidak bisa hanya belajar dari mendengar apa yang disampaikan oleh caddy senior di lapangan. Dengan adanya buku tersebut, setidaknya menumbuhkan minat mempelajari bahasa Jepang dengan lebih baik apalagi caddy merupakan pekerjaan yang diharuskan berinteraksi langsung dengan wisatawan dari negara manapun.

Dengan melihat betapa pentingnya media buku saku dalam meningkatkan kemampuan kosa kata dasar bahasa Jepang, maka "Pengembangan Buku Saku Bahasa Jepang Pariwisata Untuk Caddy Di Nirwana Bali Golf Club" dipilih sebagai judul yang tepat untuk penelitian ini. Melalui pengembangan media buku saku ini diharapkan dapat 
mengembangkan buku saku bahasa Jepang pariwisata yang sesuai dengan kebutuhan caddy di Nirwana Bali Golf Club.

Ditinjau dari latar belakang yang penulis sampaikan, maka dapat dirumuskan permasalahan yaitu " bagaimanakah buku saku bahasa Jepang pariwisata yang sesuai untuk kebutuhan caddy di Nirwana Bali Golf Club?.

\section{Metode}

Model Penelitian ADDIE. Model yang menjadi acuan dalam pengembangan buku saku bahasa Jepang untuk caddy di Nirwana Bali Golf Club adalah model ADDIE merupakan salah satu model desain pembelajaran sistematik. Menurut Benny A. (2009; 128-132), terdapat satu model desain pembelajaran yang sifatnya lebih generik yaitu model ADDIE (Analysis-Design-Develop-Impelement-Evaluate).

\subsection{Prosedur Penelitian Pengembangan}

Model desain pembelajaran ADDIE ini terdiri atas lima langkah kegiatan, yaitu sebagai berikut:

a. Analysis (Analisis)

Dari hasil analisis, berdasarkan pengambilan data berupa wawancara dan observasi tidak ada sumber buku pedoman membuat para caddy tidak mampu berinteraksi dengan golfer asal Jepang sehingga membuat pekerjaan mereka menjadi terhambat. Sedangkan para caddy tersebut memiliki minat mempelajari bahasa Jepang pariwisata khususnya di dalam dunia golf.

b. Design (Perancangan)

Hal yang dilakukan dalam tahap perancangana ini : pertama, merumuskan rumusan masalah dari hasil wawancara dan observasi yang didapat; kedua, membuat kerangka awal dari rumusan masalah dan tujuan dibuatnya media buku saku yang direncanakan; ketiga, dipertimbangkan sumber-sumber pendukung lain, semisal buku panduan player assistant yang tersedia di training centre di Pan Pacific di Niwana Bali, kondisi nyata di lapangan golf, dan kebutuhan dari pembelajaran bahasa Jepang khususnya bagi para caddy di Nirwana Bali Golf Club.

c. Development (Pengembangan)

Dalam proses pengembangan adalah tahap mewujudkan kerangka desain menjadi produk. Diawali dengan pembuatan naskah awal yang berisikan pokok-pokok pembahasan mengenai golf. Kemudian dilanjutkan dengan tahap proses pemindahan dari data aplikasi software microsoft word ke aplikasi software corel draw. Dalam menggunakan aplikasi software corel draw ini ada beberapa tahapan yaitu : memilih ukuran buku yang akan dicetak, membuat halaman buku, mengedit sampai akhirnya buku siap dicetak.

d. Implement (Impementasi)

Kemudian dilanjutkan dengan pada tahap pengumpulan data dengan metode kuesioner dengan menggunakan angket uji ahli (uji ahli materi, media dan kelayakan). Tetapi pada tahap ini belum dilakukan uji coba kelompok kecil dikarenakan pandemi COVID-19.

e. Evaluation (Evaluasi)

Pada tahap ini setelah dilakukan pengumpulan data oleh uji ahli (uji ahli materi, media, dan kelayakan) dilanjutkan dengan penyempurnaan produk berdasarkan komentar dan saran yang didapatkan dari para uji ahli. 


\subsection{Uji Coba Produk}

Tahap uji coba produk harus dilakukan untuk mengetahui apakah produk yang dikembangkan sudah layak digunakan atau belum sebelum melakukan tahap efektivitas produk. Tahap uji coba produk dalam penelitian pengembangan ini terdiri atas:

a. Desain Uji Coba

Pada desain uji coba, dalam mengembangkan buku saku bagi para caddy Nirwana Bali Golf Club menggunakan desain deskritif yang diuji validitasnya hingga tahap uji ahli meliputi uji ahli materi, uji ahli media dan uji ahli kelayakan. Tinjauan dari uji ahli dimaksudkan untuk memperoleh penilaian, saran dan pendapat terhadap validasi isi bahan ajar dikembangkan.

b. Subjek Uji Coba

Subjek pada uji ahli materi dan ahli media produk penelitian ini adalah dosen Pendidikan Bahasa Jepang yang akan menguji kelayakan mengenai isi dari materi dalam produk pengembangan buku saku. Uji ahli materi digunakan untuk mengetahui mengenai kelayakan materi dan media dari produk yang ditawarkan sebelum diuji cobakan produk kepada para caddy, uji ahli media digunakan untuk mengetahui mengenai kelayakan tampilan dari produk yang ditawarkan sebelum diuji cobakan kepada para caddy sedangkan uji ahli kelayakan dilakukan oleh perwakilan caddy digunakan untuk mengetahui kesesuain materi yang dibutuhkan caddy serta kelayakan tampilan. Oleh karena itu, menggunakan tiga uji ahli meliputi materi, media dan kelayakan.

c. Jenis Data

Jenis data dalam penelitian ini adalah angket, data yang dikumpulkan merupakan penilaian, tanggapan dan saran-saran yang diperoleh dari para ahli. Ahli materi dan ahli media berasal dari dosen pengajar di Program Studi Pendidikan Bahasa Jepang dan ahli kelayakan berasal dari perwakilan caddy di Nirwana Bali Golf Club.

\subsection{Metode dan Instrumen Pengumpulan Data}

Metode pengumpulan data dan instrumen penelitian pada penelitian ini adalah instrumen yang dipakai sebagai alat untuk mengukur validitas dan efektivitas dari rancangan yang telah dibuat. Penelitian ini menggunakan tiga instrumen penelitian yang digunakan untuk mengumpulkan dan menganalisis data, meliputi : observasi lapangan; wawancara; dan kuesioner berupa angket uji ahli yang dibagi menjadi tiga bagian yaitu uji ahli materi, uji ahli media dan uji ahli kelayakan yang nantinya akan digunakan sebagai acuan dalam pengembangan dan perbaikan produk.

a. Observation (Pengamatan)

Observasi pada penelitian ini adalah observasi partisipan, yaitu observasi yang melibatkan penelitian sebagai observer secara langsung dalam kegiatan yang dilakukan di lapangan. Observasi dilakukan pada tanggal 17 Juni 2017 dan 21 Juni 2017 di Nirwana Bali Golf Club dengan ikut serta mengobservasi para caddy dalam melaksanakan tugasnya.

b. Wawancara

Aspek pedoman wawancara dalam proses pengambilan data dapat dibedakan menjadi tiga jenis yaitu : wawancara terstrukur, tidak terstrukur dan kombinasi (Darmani,2014:311). Wawancara yang dilakukan dalam penelitian ini dilakukan dengan supervisor caddy dan perwakilan caddy di Nirwana Bali Golf Club. Wawancara dilakukan secara kombinasi antara wawancara terstrukur dan tidak teratur. Wawancara ini dilakukan pada tanggal 23 Juni dan 24 Juni 2017.

c. Angket 
Pada penelitian ini, angket digunakan pada saat menganalisis proses uji coba ahli pada uji ahli materi, media dan kelayakan. Data kuantitatif berupa penilaian validator dengan deskriptif kuantitatif. Teknik analisis ini digunakan untuk mengolah data yang diperoleh melalui angket dalam bentuk deskriptif persentase. Rumus yang digunakan untuk menghitung rata-rata dari masing-masing subjek sebagai berikut :

$$
X=\underline{\Sigma X}
$$

Keterangan:

$X=$ Skor rata-rata indikator

$\Sigma \mathrm{X}=$ Jumlah skor total indikator

$\mathrm{N}=$ Jumlah indikator

Rumus yang digunakan untuk menghitung persentase, sebagai berikut :

Persentase keidealan $=\underline{\text { Skor rata-rata }} \times 100 \%$

Skor tertinggi

Hasil Persentase tersebut menjadi dasar penilaian kelayakan buku saku, seperti yang ditunjukan pada tabel 1 .

Tabel 1. Hasil Persentase

\begin{tabular}{|l|l|l|}
\hline NO & Angka & Katergori \\
\hline 1 & $0-10 \%$ & Sangat Kurang \\
\hline 2 & $11-40 \%$ & Kurang \\
\hline 3 & $41-60 \%$ & Cukup \\
\hline 4 & $61-90 \%$ & Baik \\
\hline 5 & $91-100 \%$ & Sangat Baik \\
\hline
\end{tabular}

(Sumber : Arikunto, 2006)

\subsection{Metode dan Teknik Analisis Data}

Data yang dikumpulkan dari instrumen yang telah diisi oleh responden ditabulasikan. Selanjutnya data informasi yang telah diperoleh dari instrumen angket dianalisis dengan pendekatan deskriptif kualitatif.

\section{Hasil dan Pembahasan}

\subsection{Hasil Penelitian}

a. Penyajian Data Uji Coba

Buku yang dikembangkan dalam penelitian ini adalah buku saku yang memuat berbagai kosakata dasar bahasa Jepang bagi para caddy di Nirwana Bali Golf Club. Buku saku ini menyajikan materi meliputi (1) mengenal istilah golf, peralatan golf dan fungsinya dalam bahasa Jepang; (2) bahasa Jepang dalam dunia pariwisata; (3) menjelaskan tentang kata tunjuk dan posisi di lapangan golf dalam bahasa Jepang; (4) mengenal layout dan menjelaskan 
jarak pukul bola di lapangan golf; (5) kosa kata; dan (6) contoh percakapan. Selain itu dalam buku saku ini, terdapat ilustrasi yang akan membantu para caddy dalam memahami materi dan membuat para caddy termotivasi untuk mempelajari bahasa Jepang secara menyenangkan dan bisa menggunakan buku saku ini kapanpun dan dimanapun secara mandiri. Buku saku ini disusun menggunakan huruf hiragana yang diikuti dengan huruf romaji sebagai cara baca, karena buku saku Bahasa Jepang pariwisata untuk caddy dengan materi dan pemaparannya masih bersifat sederhana dan dibuat agar mudah dimengerti oleh para caddy di Nirwana Bali Golf Club. Selanjutnya, gambar yang digunakan merupakan gambar yang diambil langsung di Nirwana Bali Golf Club. Adapun struktur dari buku saku yang telah disusun yaitu sebagai berikut:

a) Sampul Depan

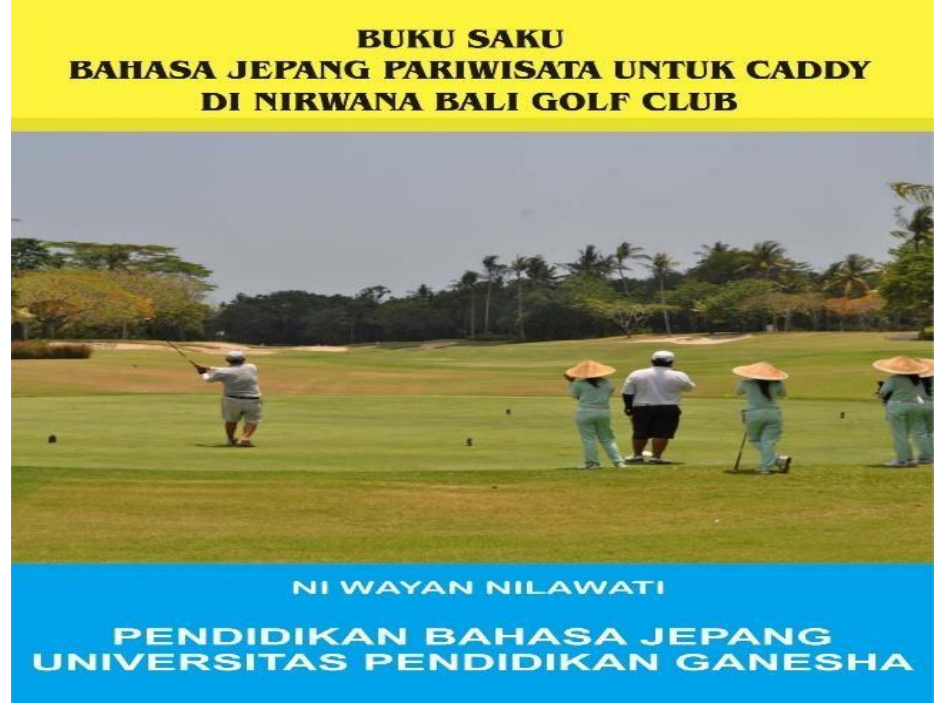

Gambar 1. Sampul Depan Buku Saku

b) Kata Pengantar

Kata pengantar dalam buku saku ini terdapat pada bagian awal buku diperuntukkan bagi para caddy Nirwana Bali Golf Club. Kata pengantar menuliskan paparan dari isi buku secara singkat dan ucapan terimakasih kepada pihak yang telah membantu dalam proses pembuatan buku saku.

c) Daftar Isi

Pembuatan daftar isi ini diharapkan mampu memudahkan para caddy dalam mencari materi yang ingin dipelajari.

d) Penyajian Ilustrasi 


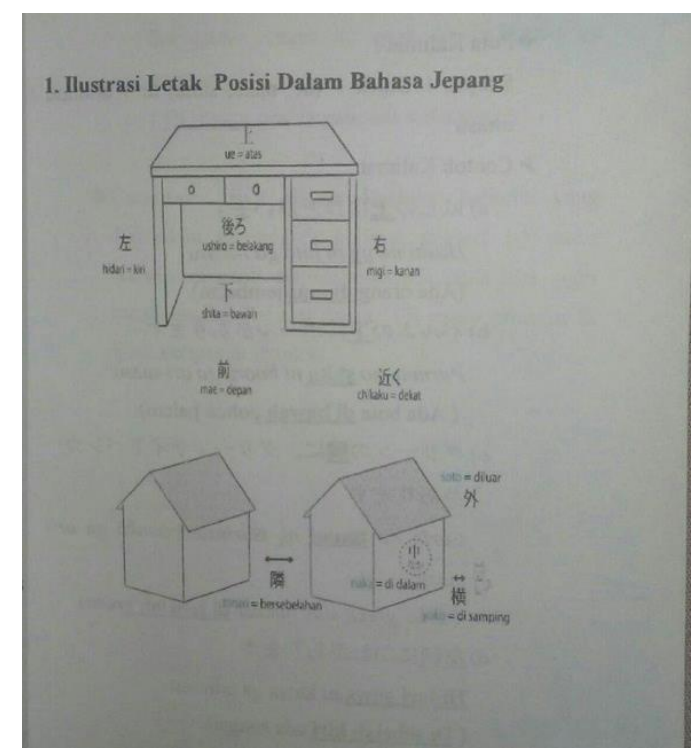

Gambar 2. Penyajian Ilustrasi

Penyajian ilustrasi diperuntukkan agar memudahkan para caddy dalam memvisualisasikan suatu tulisan/informasi. yang diharapkan dengan bantuan visual tersebut materi lebih mudah dicerna.

e) Contoh Percakapan

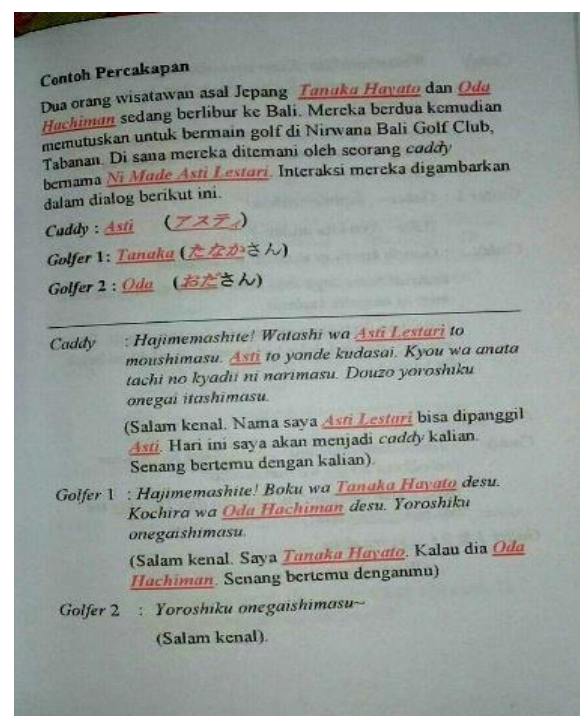

Gambar 3. Contoh Percakapan

Contoh percakapan digunakan untuk memberi contoh interaksi antara caddy dan golfer dalam bahasa Jepang di dunia nyata.

f) Hasil Angket Uji Ahli 
Penilaian angket menggunakan penilaian skala 5 yakni, Penilaian angket menggunakan penilaian skala 5 , yakni Sangat Baik $(S B)=5$, Baik $(B)=4$, Setuju $(S)=3$, Kurang $(K)=2$, Sangat Kurang $(S K)=1$.

Angket uji ahli materi diberikan kepada dosen Program Studi Pendidikan Bahasa Jepang, Universitas Pendidikan Ganesha. Persentase total skor untuk uji ahli materi adalah 85 dengan kualifikasi 'baik'. Angket uji ahli media diberikan kepada dosen Program Studi Pendidikan Bahasa Jepang, Universitas Pendidikan Ganesha. Persentase total skor untuk uji ahli media adalah 80 dengan kualifikasi 'baik'. Angket uji ahli kelayakan diberikan kepada caddy di Nirwana Bali Golf Club. Persentase total skor uji ahli kelayakan adalah 92 dengan kualifikasi 'sangat baik'.

g) Hasil Analisis Data

Sebelum menghasilkan buku saku yang layak digunakan, dilakukan tahap uji ahli terlebih dahulu agar menghasilkan produk yang berkualitas dan sesuai dengan kebutuhan responden. Buku saku yang dihasilkan sudah melalui beberapa tahapan perbaikan dengan memperbaiki penggunaan bahasa Jepang dan desain buku agar sesuai dan menjadi lebih menarik. Tahap uji ahli dilakukan oleh tiga orang penguji ahli. Penguji ahli materi dan media merupakan dosen Program Studi Pendidikan Bahasa Jepang Universitas Pendidikan Ganesha, dan uji ahli kelayakan dari salah satu perwakilan caddy di Nirwana Bali Golf Club.

Berdasarkan penilaian yang diberikan oleh ahli materi, berdasarkan hasil validasi tersebut ahli materi memberikan kesimpulan bahwa media pembelajaran bahasa Jepang berupa buku saku tersebut layak untuk digunakan dengan revisi sesuai saran. Ada beberapa catatan/saran yang diberikan oleh ahli materi yaitu penulisan huruf harus konsisten jika semua huruf pada kata pertamanya huruf besar, maka semua harus sama.

Berdasarkan penilaian yang diberikan oleh ahli media, berdasarkan hasil validasi tersebut ahli media memberikan kesimpulan bahwa media pembelajaran bahasa Jepang berupa buku saku tersebut layak untuk digunakan dengan revisi sesuai saran. Ada beberapa catatan/saran yang diberikan oleh ahli media yaitu rapikan margin karena ada yang tidak sama.

Berdasarlan penilaian yang diberikan oleh ahli kelayakan, berdasarkan hasil validasi tersebut ahli kelayakan memberikan kesimpulan bahwa media pembelajaran bahsa Jepang berupa buku saku tersebut layak untuk digunakan dengan revisi sesuai saran. Ada beberapa catatan/saran yang diberikan oleh kelayakan yaitu perbanyak lagi kosa kata bahasa Jepang yang digunakan yang sesuai dengan di lapangan agar memudahkan caddy dalam bekerja dan berinteraksi dengan golfer.

h) Revisi Produk

Berdasarkan saran dan komentar dari uji ahli materi, pada penulisan huruf harus konsisten jika semua huruf pada kata pertamanya huruf besar, maka semua harus sama. Isi materi sebelum dan sesudah direvisi dapat dilihat pada Gambar 4 dan 5 


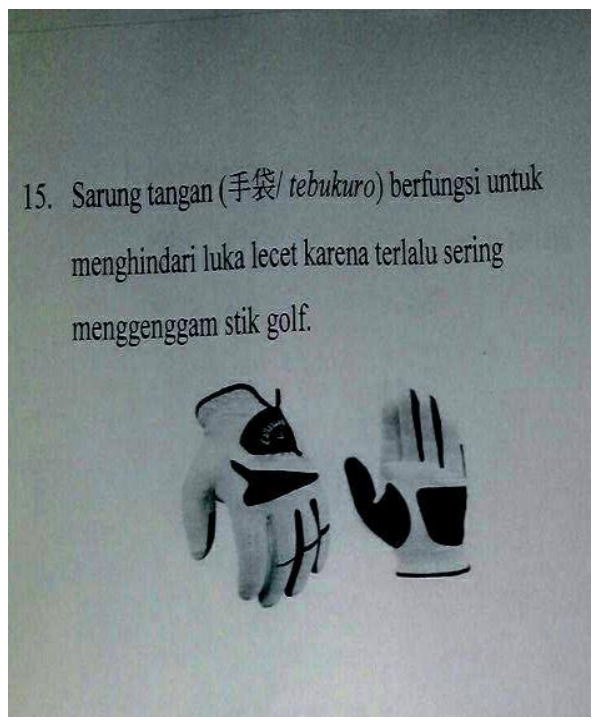

Gambar 4. Tampilan isi materi sebelum revisi

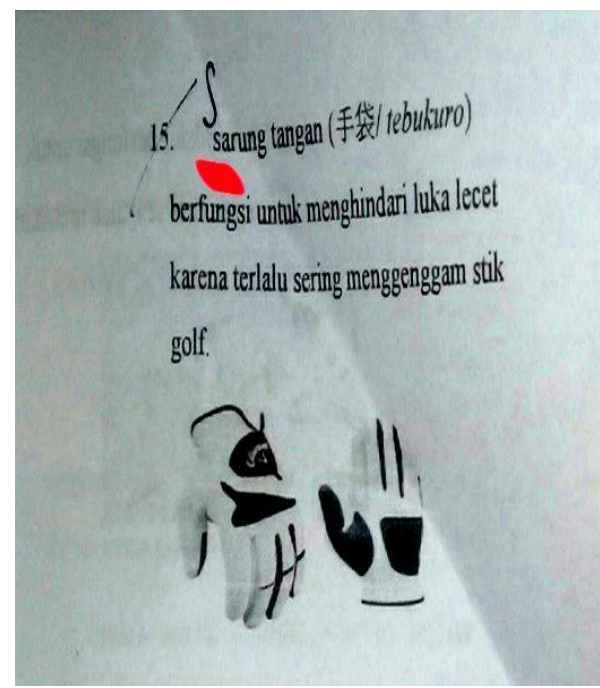

Gambar 5. Tampilan isi materi sesudah revisi

Berdasarkan saran dan komentar dari uji ahli media yaitu rapikan margin karena ada yang tidak sama. Isi media sebelum dan sesudah direvisi dapat dilihat pada gambar 6,7,8, dan 9 . 


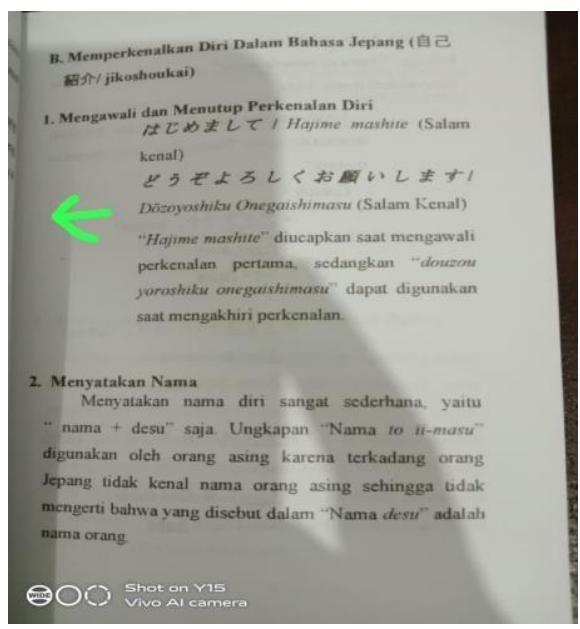

Gambar 6. Tampilan isi media sebelum revisi

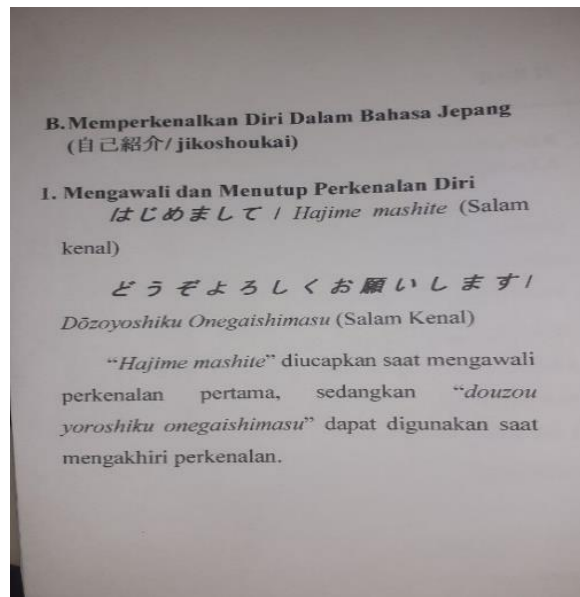

Gambar 7. Tampilan isi media setelah revisi

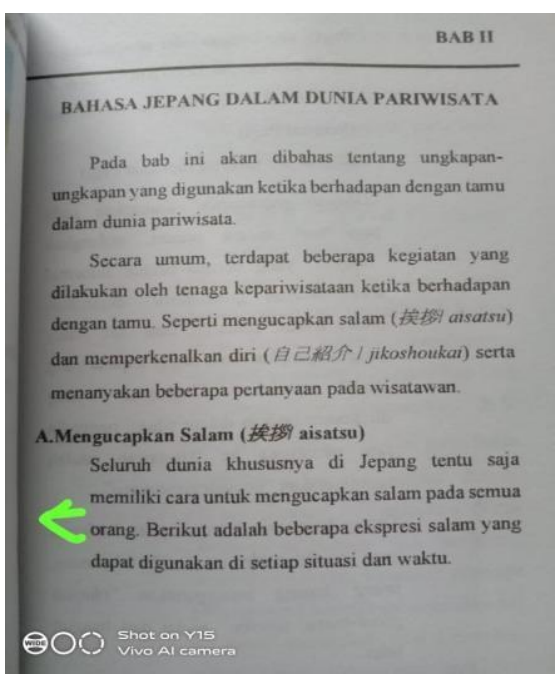

Gambar 8. Tampilan isi media sebelum revisi 


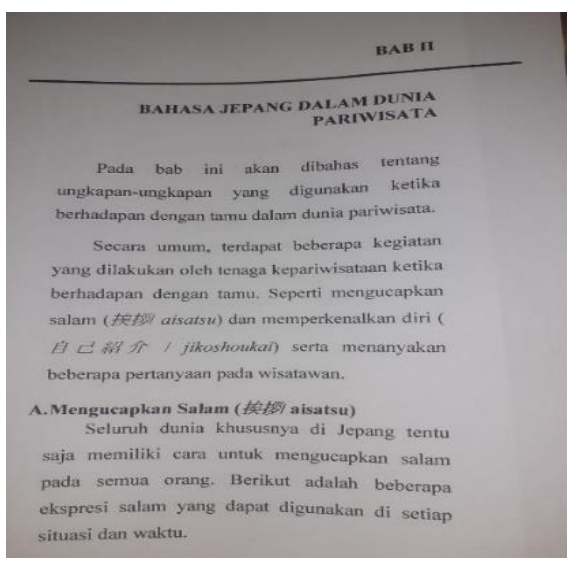

Gambar 9. Tampilan isi media setelah revisi

Berdasarkan saran dan komentar dari perwakilan caddy yaitu perbanyak lagi kosa kata bahasa Jepang yang digunakan yang sesuai dengan di lapangan agar memudahkan caddy dalam bekerja dan berinteraksi dengan golfer. Hasil akhir setelah direvisi dapat dilihat pada Gambar 10.

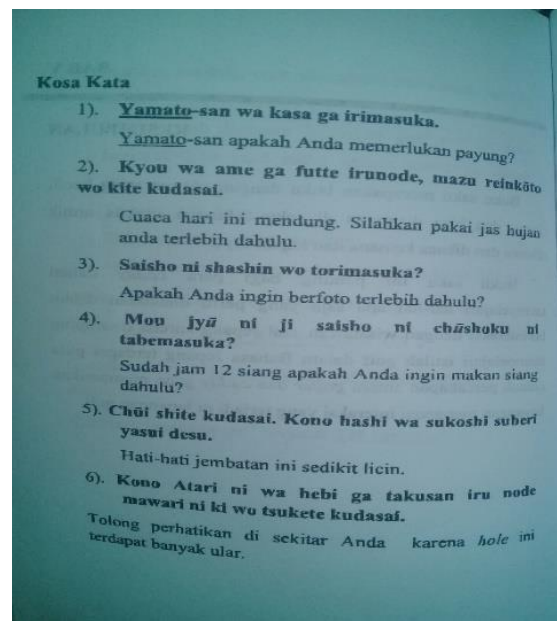

Gambar 10. Hasil akhir sesudah revisi

\subsection{Pembahasan Hasil Penelitian}

Berdasarkan latar belakang yang telah dipaparkan pada bab I, penelitian ini dilakukan karena sampai saat ini masih belum tersedianya buku saku bahasa Jepang Pariwisata untuk caddy di Nirwana Bali Golf Club.

Dalam penelitian ini untuk mengetahui produk dalam penelitian ini layak digunakan atau tidak, penulis menggunakan metode penilaian angket. Penilaian angket pada penelitian ini menggunakan metode penilaian skala 5 yaitu : Sangat Baik $(S B)=5$; Baik $(B)=4$; Sedang $(S)=3$; Kurang $(K)=2$; Sangat Kurang $(S K)=$ 1. Berdasarkan hasil penyajian angket dalam tahap validasi uji ahli materi, uji ahli media serta uji ahli kelayakan hasil validasi menunjukkan bahwa tingkat validasi uji ahli materi berada pada kategori baik, uji ahli media pada kategori baik 
sedangkan uji ahli kelayakan berada pada kategori sangat baik. Sehingga dapat disimpulkan bahwa buku saku ini sudah layak dan sesuai.

Supervisor caddy di Nirwana Bali Golf Club menjelaskan bahwa pengembangan buku saku untuk caddy ini sangat diharapkan karena pengenalan bahasa Jepang pariwisata ini membuat para caddy termotivasi lebih giat lagi dalam mempelajari istilah golf dalam bahasa Jepang, begitu pula dengan para caddy ini sangat membantu karena selain buku saku ini mudah dibawa dimanapun dan kapanpun juga terdapat ilustrasi yang memudahkan dalam memahami materi serta isi materi singkat, jelas dan padat.

Buku saku pariwisata untuk caddy ini telah disusun berdasarkan model pengembangan ADDIE (Analysis-Design-Development-Implement-Evaluation). Dimulai dari tahap: analysis dengan melakukan wawancara terbuka dan observasi lapangan; kemudian dilanjutkan dengan tahap design atau perancangan dengan menentukan format, konsep serta ilustrasi buku saku; dilanjutkan dengan tahap development atau pengembangan yang merupakan tahap eksekusi pembuatan produk dengan menggunakan buku pedoman player assistant sebagai acuan pembuatan produk; dilanjutkan dengan tahap Implement yang dilakukan dengan pengumpulan data verifikasi produk oleh uji ahli materi, uji ahli media dan uji ahli kelayakan; kemudian tahap Evaluation setelah produk lolos uji ahli masih dilanjutkan dengan revisi dan penyempurnaan produk. Setelah penyempurnaan produk rampung, buku saku siap dicetak dan digunakan oleh para caddy.

Berdasarkan hasil penilaian dari validator, buku ini sudah layak digunakan sebagai buku saku pariwisata untuk para caddy di Nirwana Bali Golf Club karena sudah melewati tahap uji ahli materi, media dan kelayakan. Kelayakan penggunaan bahasa Jepang pada buku saku ini sudah dinilai oleh ahli materi dan ahli media yang merupakan salah satu dosen Pendidikan Bahasa Jepang di Universitas Pendidikan Ganesha dan kelayakan penggunaan bahasa Jepang pada buku saku ini sudah dinilai oleh perwakilan caddy di Nirwana Bali Golf Club.

Berdasarkan paparan diatas, diharapkan buku saku pariwisata untuk caddy Nirwana Bali Golf Club ini dikembangkan sehingga dapat digunakan oleh para caddy sebagai sumber belajar bahasa Jepang untuk meningkatkan motivasi dan keterampilan berbahasa Jepang.

\section{Simpulan dan Saran}

Simpulan yang dapat dirumuskan yaitu buku saku yang dikembangkan di Nirwana Bali Golf Club adalah buku saku bahasa Jepang pariwisata yang lebih menonjolkan pada kosakata dasar dan terdapat ilustrasi agar memudahkan para caddy dalam memahami bahasa Jepang pariwisata. Selain terdapat pola kalimat yang dapat membantu caddy dalam memahami kalimat atau kosakata bahasa Jepang terdapat pula contoh-contoh percakapan bahasa Jepang sesuai dengan situasi nyata di lapangan golf.

Buku saku ini terdiri 4 bab yang disusun secara berdasarkan analisis kebutuhan melalui wawancara, observasi lapangan serta buku pedoman dari player assistant training program. Terdiri dari 4 bab yang dibagi menjadi : Bab I mengenal istilah golf, peralatan golf dan fungsinya dalam bahasa Jepang; bab II Bahasa Jepang dalam dunia pariwisata; bab III menjelaskan tentang kata tunjuk dan posisi di lapangan golf dalam bahasa Jepang; bab IV mengenal layout dan menjelaskan jarak pukul bola di lapangan golf.

Kepada manajemen di Nirwana Bali Golf Club diharapkan memberikan program pelatihan bahasa asing khususnya bahasa Jepang bagi caddy. Buku saku ini diharapkan 
mampu meningkatkan motivasi para caddy dalam mempelajari bahasa Jepang di kondisi yang belum adanya pelatihan bahasa Jepang di Nirwana Bali Golf club.

\section{Daftar Pustaka}

Arikunto, S. 2006. Prosedur Penelitian Suatu Pendekatan Praktik. Jakarta: Rineka Cipta.

Darmani, H. 2014. Metode Penelitian Pendidikan dan Sosial. Bandung: Alfabeta. Dharmini,

Ary. 2018. "Pengembangan Buku Panduan "Scuba Diving Nihon Go Kaiwa" Untuk Instruktur Diving Di Matahari Dive Tulamben". Widya Laksana, Volume 4, Nomor 3 ( hlm. 273 ).

Japan Foundation. 2020. "Survey Report On Japanese-Language Education Abroad 2018". Tersedia pada http://www.jpf.go.jp/e/project/japanese/survey/result/survey18.html (diakses tanggal 6 Maret 2021).

Pribadi. 2009. Model Design Sistem Pembelajaran. Jakarta: Dian Rakyat.

Putra. 2013. Research and development. Jakarta: Rajagrafindo Persada.

Sudjianto, D. 2004. Pengantar Linguistik Bahasa Jepang. Jakarta: Kesaint Blanc.

Sutedi, D. 2007. Nihongo No Bunpou (Tata Bahasa Jepang Tingkat Dasar). Bandung: Humaniora.

Setyosari. 2013. Metode Penelitian dan Pengembangan. Jakarta: Kencana Prenadamedia Group.

TripAdvisor. 2019. "Destinasi Populer Dunia”. Tersedia pada https://www.tripadvisor.co.id/TravelersChoice-Destinations.html (diakses tanggal 6 Maret 2021). 